\title{
Understanding Student-Teachers' Performances within an Inquiry-Based Practicum
}

\author{
Pilar Méndez Rivera ${ }^{1}$ \& Francisco Pérez Gómez ${ }^{2}$ \\ ${ }^{1}$ Sciences and Education Faculty, Doctoral Programme Studies in Education, Universidad Distrital Francisco \\ José de Caldas, Bogotá, Colombia \\ ${ }^{2}$ Faculty of Humanities, Languages Teaching Programme, Universidad Pedagógica Nacional de Colombia, \\ Bogotá, Colombia \\ Correspondence: Pilar Méndez Rivera, Calle 25 No. $43^{\text {a }} .49$ Apto. 301, Bogotá-Colombia. E-mail: \\ pmendez@udistrital.edu.co
}

Received: February 17, 2017 Accepted: March 18, 2017 Online Published: March 20, 2017

doi: 10.5539/elt.v10n4p127 URL: http://doi.org/10.5539/elt.v10n4p127

\begin{abstract}
The role of an inquiry-based practicum in the education of future teachers has been identified as a key component to foster student-teachers' abilities to face problems, try to solve them, work on doubts and produce situated and valuable learning from their own practices (Cochran-Smith \& Little, 2001; Beck, 2001). The interaction between mentors and student-teachers involved in this process requires feeding the mutual understanding to collaboratelly make decisions to work on difficulties. In this reflective study, the practicum was the perfect scenario to evaluate how student-teachers and mentors engaged in inquiry-based work to face problems on a daily basis in schools in the context of teachers education. This article shows how a group of 12 student-teachers and their mentors experienced difficulties within an inquiry-based practicum in an undergraduate programme while conducting an instructional intervention, designing, implementing and applying a project relevant to their teaching context. Given the qualitative nature of this study, some stages of the process were analysed over a period of a year, bringing as a result relevant insights to enhance their teaching practicum-process in Colombian public schools.
\end{abstract}

Keywords: inquiry-based practicum, instructional intervention, reflection, teachers-education

\section{Introduction}

Bachelor programmes in EFL from some Colombian universities require their student- teachers to develop not only linguistic and pedagogical skills but also inquiry skills in the classroom and in the school context. Nevertheless, to apply the principles of an inquiry process into a teaching practicum turns out to be a very overwhelming task for both student-teachers and mentors. Two mentors precisely conducted this study over a year of observation, with interviews, reflective journals and sessions to explore how these participants handled such principles and to identify some difficulties and opportunities for improvement. To accomplish that inquiry cycle, the teaching programme under study organised its syllabi content focusing on a problem-based methodology to help their student-teachers to have a questioning mind in order to inquiry their own practices trying to solve problems, set clear objectives, and have sustained stances. Thus, it was expected that in the practicum, students could design an instructional intervention based on their own inquiries about teaching in specific school contexts.

Student-teachers knew their teaching practicum should be conducted under the basis of inquiry; however, when we as mentors observed them, we realised that they struggled with their instructional design despite the fact that they were provided with the elements to do it in their teaching programme. During the first semesters of that programme, student-teachers reinforced the linguistic aspects of English (syntactical, semantic, phonological, phonetic and grammar aspects), and studied the epistemological and pedagogical foundations to be a teacher.

Some studies revolving around the dynamics of a teaching practicum have tackled the importance of the relationship between theory and practice (Bonilla \& Méndez Rivera, 2008; Olaya \& Gómez, 2013). In this sense, the student-teachers were exposed to the theoretical foundations based on an inquiry teaching in their first cycle of education; whereas in the middle of their studies, they had to face their first practicum at school in the primary 
level of education. Here, the difficulties of being an English teacher started being evident, and all the theories learnt in the previous semesters came to make the classroom an experiential context of methodological, epistemological, and pedagogical approaches. Student-teachers were asked to observe the real context of primary and secondary schools and identify phenomena that might affect the expected teaching/learning processes they had planned.

To provide further contextualisation of the way the practicum is conceived in the setting studied, it is important to explore some of the conditions the participants of this study had to meet. One of the first requirements they had to fulfil was the design of a lesson plan. Before their actual practicum, student-teachers learnt about a comprehensive set of teaching methods and approaches in a course called Methodology of Foreign languages. Hence, they were supposed to design their lessons plan, choosing the most suitable approach. To contextualise those plans to the realities of the school became a matter of thinking critically and reflecting on making an appropriate decision. In fact, most of the problems we identified as mentors were related to the lack of coherence between theory and practice- a variety of activities prepared by the student-teachers had nothing to do with the reality of the context or with the styles of learning of the children in the classroom. Activities were just "copied" and "transferred" acritically from books and even from the Internet, without a connection between the theoretical and practical rationale that reflected the core theory supporting them. It was expected that student-teachers fulfil the inquiry cycle (questioning the world, formulating appropriate questions, looking for suitable ways to answer them, solving problems while learning English, helping their own students to have an inquiry mind) by applying what they had learnt through inquiry but regrettably, when we as mentors observed them we realised they continued to repeat the same content-transmission mode of teaching where their students were just merely passive receivers of information.

Another aspect reported to evidence the existence of issues and difficulties in the teaching practicum of this EFL programme was the one regarding the coherence between the different visions of language, learning, and teaching student-teachers were confronted to, in order to relate theory and practice, and to connect what it was done in the classroom with the methodological approaches they had been already taught; notwithstanding, we identified that there were major doubts and confusion when sustaining it. Namely, their difficulties to transform the grammar focus of the school curriculum to a more communicative and contextualised one. Thus, their pedagogical and instructional design was decontextualised, not reliable and poorly supported.

From a global perspective, a practicum is a complex scenario due to the different layers of analysis involved. On the one hand, it provides possibilities for understanding the significance of being a teacher at public schools, where English is a mandatory curricular subject whose learning must be improved. The complex nature of a practicum is evident in the Colombian institutions dynamics and demanding programmes, projects and practices mandated by the Minister of Education and Health such as participating actively in teachers' meetings, taking part in parents' meetings, planning and leading cultural and academic school events, understanding extracurricular interventions, vaccination and snack time, social welfare campaigns to control pupils' height and weight, and inclusion of minorities and children with special needs.

Theoretically speaking, a practicum offers the conditions to set the preparatory ground for teachers' education through a steady and serious collaborative inquiry-based work among student-teachers, mentors and head teachers (Nguyen, 2009). A practicum based on these principles, makes observation a key and determinant factor. That was how to mentors' eyes, the observation became an opportunity to help their student-teachers to find out their personal, professional and teaching potentialities, to maximise their strengths, to provide prompt feedback on most likely solutions to problems that arose in class, to detect whether there was a conjunction between what was planned and what was done, and if they really applied the principle of the method or approach they had chosen, among others. Conversely, to student-teachers' eyes observation was in principle, an uneasy, unpleasant, and defying experience. To balance these two positions out, it was necessary that in a mutual effort and understanding, student-teachers and mentors involved in this study, agreed that periodical observations should be a key element for student-teachers' education inasmuch as constant reflection upon what was observed could result in quality feedback which in turn, could leave those student-teachers with the feeling that they were being well supported, and not just tested.

This study contributes to the understanding of the complex nature of a teaching practicum, the significant roles that mentors and student-teachers play within an inquiry-based model to promote critical pedagogies more interested in language as a means, and not as an end. It is expected that when these insights and reflections be socialised and discussed institutionally, they might impact the syllabus and curriculum design as well as the profile of mentors and student-teachers. 


\section{Method}

As suggested by Burns (1999), this study is defined as an action research which followed a small-scale process to involve student-teachers and their mentors in a collaborative and reflective action intended to improve their teaching practicum experience on a short-term basis, and to enhance the teaching practicum conditions for them and their advisors on a long-term basis. As a qualitative study, the procedures used to obtain information were mainly focused on the reflections and perceptions of student-teachers which were collected through different instruments. Bearing this in mind, the results that will be presented later on were based on descriptions of some key aspect explored by stages during the one-year observation process.

\subsection{Data Collection Instruments}

Sufficient insight was obtained from student-teachers' journals, reflections derived from regular meetings, reflective logs and interviews as set forth by Burns (2010), Mills (1999) and others, to try to respond the exploratory question: how might the constant observation of an inquiry-based practicum reveal insights to help student-teachers to identify difficulties and teaching growth opportunities? Due to the descriptive nature of the data, the triangulation process as Sagor (2005) explains synthesised groupings and merged commons patterns to explain the phenomenon.

\subsection{Participants (Subjects) Characteristics}

A formal consent letter was provided to two groups of student-teachers who were in their first year of teaching practicum. Those participants were informed of the ethical issues and considerations implied in this qualitative study in order to obtain their will to participate and share relevant, personal reflections on their experiences through different instruments. As researchers, we decided in common agreement that the results displayed in this study shall be focused on the reflections and perceptions which arose from the constant interaction with participants, and not from the samples as such. Let us remember that this article is not intended to yield generalisations and prescriptions on the way teaching practica should be carried out but to shed some light on the way a practicum experience might be enhanced and maximised.

\subsection{Research Setting}

To be able to understand what participants in this study were supposed to do, and the type of practicum they carried out, it is relevant to describe what an inquiry -based practicum is, and what it entails.

Broadly speaking, the practicum which encompassed the setting for this study was characterised as being the scenario to blend theory and practice; we as researchers acknowledged that theory and practice relations have a complementary and even indissoluble character (Méndez, 2013). The role of an inquiry-based practicum deals with the students' capacities to relate, articulate and inform their practice. These capacities are the result of a questioning mind that tries to solve problems, ask situated questions and self-assess the procedures, beliefs, and decisions that have been made before, during and after a class within a multi-factorial focus. As part of the inquiry-based practicum, we guided our student-teachers to embrace the inquiry cycle to teach English through the lens of a critical reading of the context, which means adopting an informed involvement and a cautious look in front of several aspects: the roles of student-teachers, the role of their students, the role of their head teachers, and the role of their mentors; the functionality and relevance of the teaching procedures and strategies, integration of students' needs and student-teachers'expectations and plans, appropriation and recognition of methodological procedures based on a reflective practice (Méndez \& Bonilla, 2016).

Another defining feature of the practicum carried out by participants was its reflective and critical thinking nature. Being reflective and critical is an important component of teachers education in EFL. Indeed, the pedagogical models inspired by reflective and critical pedagogies (Richards \& Lockart, 1994; Norton \& Toohey, 2004) were really useful to achieve that aim for they depict student-teachers as exploring individuals who are able to transform their immediate reality in class, their teaching practices, and the teaching of English as a means to understand better their possibilities and capabilities to explain what they do, and why they do it. According to Born (2003) and Johnson (1999), this type of reasoning favours teachers' cognitive processes because when they reflect upon their own practice, such reflections help them to construct knowledge, conceptualise and confront beliefs about what is happening inside and outside the classroom. This means that teachers enhance their inquiry skills to be able to grasp their teaching reality in a double dimension: reflection in-action and reflection on-action (Schon, 1983).

It terms of the population participants had to teach, the practicum they conducted over a year targeted primary and secondary school students, and commenced half way through their language teaching major. It means student-teachers had already gained some theoretical and practical guidance to be in charge of an English class. 
In this initial practicum stage, student-teachers had to observe their school context, and specifically, their classroom. This observation implied writing descriptions, reflections, and future actions in journals and field notes (Linn \& Jacobs, 2015). From results obtained through observation, student-teachers started thinking of a pedagogical proposal appropriate to overcome the most relevant difficulties identified in a specific class. For this pedagogical proposal, they needed to plan an instructional design or pedagogical intervention, which would be applied later on in the next practicum stage where they were expected to be fully responsible for leading the class. This instructional design entailed thinking of the interrelation between a vision of language, a vision of learning, a vision of teaching, a methodology, and some assessment criteria. The way in which student-teachers interrelated these aspects informed us about their practice and as well shed some light onto a course of action for themselves, for mentors, and for head teachers to try to overcome difficulties and enhance abilities diagnosed in these novel teachers. As mentors, we suggested that the assessment criteria be socialised well in advance with all the involved persons so that the assessment process could hold its relevance, pertinence and reliability.

As stated above, one important task that student-teachers were expected to fulfil in their practicum was to make and instructional design. That instructional design may adapt the form of pedagogical projects or pedagogical proposals to both facilitate learning and assess students' teaching skills within a frame of education as inquiry (Wiggins \& McTighe, 1998). A revision of literature in the design field reveals that pedagogically solid design projects have clearly defined outcomes that recognise the setting and the population; promote student-centred, collaborative work and higher order thinking; and possess a clear vision of methodological and pedagogical concepts. Some design principles in the literature (Biggs, 2003; Bransford et al., 2006; Nicol \& MacFarlane-Dick, 2006; Reigeluth, 1999) give general guidance to teachers based on reflection and self-regulation processes. Some others offer pedagogical patterns projects to guide teachers (Bergin, 2002; Goodyear \& Yang, 2009; Mor \& Winters, 2007) with steps, principles and desired outcomes.

The description of an instructional approach was useful to help student-teachers to design a pedagogical project that held enough potential to engage their learners in tasks while they, as student-teachers reflected on what happened during the whole process. It means a pedagogical project based on student-teachers' concerns about English teaching, English learning, EFL settings, students' interests and difficulties, etc. In other words: "doing with understanding" (Barron et al., 1999) as the key element to solving problems and being able to set a course of action to guide a better practice. Here, action-research procedures challenge traditional teaching based on the delivery of information, provoking an active process of inquiry, where student-teachers are affected by their own reflective process, obtaining useful information, data, and insights to improve what they are doing. It includes a broader view of actions, actors, circumstances, interests that interfere with the processes of teaching and learning.

As it can be seen, the practicum setting where our student-teachers were involved advocated for the development of key skills such as being reflective, being critical, relating theory and practice, making and leading and instructional design, among others.

\section{Results}

After the triangulation process suggested by Sargon (2005), we synthesised the amount of data collected and focused on common patterns shared by the twelve participants. For analytical purposes, these patterns were related to the main stages of the practicum as valuable constituents to think about the difficulties identified.

\subsection{Misunderstanding the Practicum Setting}

To understand their practicum setting, student-teachers were asked to describe that context in a critical way to decide the type of teaching they needed to conduct to make students improve their English learning and increase their motivation. They were expected to be able to formulate a set of questions or problems that directed the inquiry to plan a situated practice (Wiggins \& McTighe, 1998). In doing so, they had to describe in depth aspects of the school, population, school teaching plans and principles, staff and community atmosphere, and projects being carried out. Observation sessions must be conducted to explore context looking for general information about students' profile, teachers' profile, books and materials, focus on language, pedagogical approach, behaviour; specific information about classroom management and students' responses.

Some of the difficulties that student-teachers reported to have experienced in this part of the process were related to the insufficient amount of time devoted to understanding the context, since the time allotted to do so was not as long as it should be. During a short period of time, student-teachers had to decide upon the type of instruments, procedures, and elements to make inquiries about that context. We could observe that they did not grab the complexity of the teaching setting, and that they were not able to relate the information obtained in different aspects. Given this situation, we recommend performing this task with some initial questions to be answered; 
most of them did it without any pre-established agenda, so their notes were spontaneous ideas that at the end were presented in a disarticulated way without a deep reflection process. Those student-teachers, who prepared themselves to do the task, reread mentors' instructions and looked for information to conduct a better reading. Some pre-established questions were enriched during the observation process with insights and possible implications. Here, mentors should help their student-teachers to realise the importance of some context issues to do a better job.

In regard to the information related to head teachers' profile, student-teachers informed that it had not been easy to approach their head teachers in order to have them answer questions about themselves. Thus, the only information student-teachers could gather was the one obtained through class observation. One of the aspects they mentioned as a concern was the ratio of Spanish use in costrast to English use. Namely, student-teachers complained about the overuse of Spanish in English class, and about the use of traditional techniques as code switching to make students understand more easily; therefore, to student-teachers' eyes interaction in the foreign language was scarce or limited. On the other hand, the initial perception that they had on the English head teachers' role was that these were language-centred, and consequently student-teachers did not focus on other important aspects such as the rapport head teachers gained, the classroom management they had, the grouping techniques they used, among others.

By requiring student-teachers to explain better their perceptions on head teachers, we realised that they regarded them as the most defining agents in the teaching-learning process of English, and left aside other elements that might have contributed to that process effectively as the factors related to the school, the community, the students' family support and students' participation.

\subsection{Difficulties to Make and Lead an Instructional Design Appropriately}

When we as mentors were guiding student-teachers to carry out their pedagogical projects; an instructional strategy had to be developed to guarantee the comprehension of some unavoidable concepts, procedures, and processes (how to plan a lesson, how to conduct a needs analysis, how to plan activities, how to write down objectives, how to choose the most suitable method or approach for their population and their level, etc.) to achieve a project overview and its rationale. Theory- informed design (Conole \& Dyke, 2004) has great potential to interrelate theory with the desired features of learning, and then to map relevant tools and resources to master major goals by giving feedback on the problems and difficulties of their design and implementation. In our case, this feedback took the form of questions to invite our student-teachers to sort out and go further with their intervention plan.

Due to their lack of experience, student-teachers were not always sure about how to proceed when they had to write down their instructional design. Most of them preferred to have samples to be used as a checklist to follow. However, adhering to these templates affected the creativity and natural flow of ideas and, not to mention the fact that they ended up overusing them for every single class regardless of the method, following the same template as a rule of thumb. As we provided the templates to student-teachers, we encouraged them to go beyond the format and transform it to their necessities.

To compensate for this situation, some readings were carried out all along the practicum to illuminate the design process and the discussion sessions. For us mentors, it was important to stimulate conversations and debates to help them to think aloud to provoke reflection, ideas, self/peer assessment, and critiques (Candy et al., 1994); in this way we could guarantee they did not see the format as a fixed and unchangeable tool. In our view, it was important to encourage learners to actively take control of their own practice and learning (Biggs, 1999; Dart, 1998) while they were discussing with their peers and mentors the assessment to receive support, insights, and constructivist criticism.

\subsection{Conducting Learning Needs Analyses Ineffectively}

To conduct a learning needs analysis student-teachers are expected to move from a teacher-fronted to a learner-centred emphasis. Once they have done that effectively, they can plan their pedagogical intervention more easily. A needs analysis helps student-teachers to know better what their students' interests are as well as their problems. It reveals problems, gaps, possible solutions to establish what the most suitable course of action is. As mentors, we expected relevant data about social, cultural, political dimensions to incorporate inquiry-based lessons as an opportunity to English class beyond a disciplinary focus.

In this respect, it was found that some student-teachers focused just on grammar aspects because it was easier for them to grade grammar tests and exams than obtain a general view of other skills and behaviours. When they submitted their tests or exams for revision, we as mentors, had the impression they were using online material 
without any awareness of their teaching context which could validate the use of such material.

Another issue derived from student-teachers not having conducted a thorough and rigorous needs analysis, lay in the fact that too much attention was paid to statistic information related to age, number of students, gender, socioeconomic background, little was said on each and one of the communicative skills and sub skills, and not to mention the students' needs in terms of the equally important savoir, savoir faire, savoir etre and savoir apprendre competences (Deloirs,1994), which were neglected. Doing a well-defined and complete needs analysis not only could help student-teachers to understand their most immediate reality in the classroom but also characterise and ultimately diagnose their population more accurately so that they could identify issues more objectively.

\subsection{Difficulties to Embrace a Project-Based Teaching}

It is important to clarify before hand that irrespective of the fact student-teachers had to conduct or not a research project as a graduation-conducive requirement, it became crucial that all of them should show ownswership and commitment to their pedagogical project, which was meant to be their guidelines and not their teaching "bible", particularly if they claimed to work under the dynamic and always changing nature of an action-research oriented project.

The pedagogical project that student-teachers were expected to devise should be organised around a set of questions or a problem that embodied the pedagogical intervention, tasks, and activities to try to solve it. The notion of problem was not understood as something bad or a negative situation, quite the reverse, a problem was defined as an opportunity for improving or enhancing a given situation or even a great chance to maximise or make the most of resources that were believed to benefit their students. A good pedagogical project is one which serves as a guide to incorporate theoretical support and conduct teaching strategies. For us, this strategy might guide student-teachers to consolidate theory and practice to help their students to develop not only communicative skills but higher order thinking ones such as suggesting solutions to a problem, debating ideas, having clear stances, identifying gaps among others. When we checked their pedagogical proposal, we found out that despite knowing its requirements, conditions, implications and features, student-teachers mostly incorporated an unclear problem statement, a vague research question, grammar oriented approaches, and an array of unconnected activities.

Another difficulty reported by student-teachers was making the project rationale. They acknowledged the importance it had for them because it could provide an explanation of the purposes aimed at in their project, it could situate it within a framework, and it could give a justification for it. Nevertheless, it was precisely in this stage of the project, where student-teachers struggled the most to make a connection between what they wished to do with their proposal and what the school was pursuing with its local policies. In this sense, the aims set forth in the rationale seemed to go in two different directions as student-teachers failed to give an account of that reality, and some of the proposal ended up being too ambitious and, therefore became not feasible.

\subsection{Planning Disjointed Lessons}

The planning stage in a teaching practicum is intended to answer these questions: What do student-teachers intend for their class? Why do they intend this? How might they do this? It means a brief description of what is behind their planning process in terms of teaching and learning goals. In planning, setting up teaching goals and learning objective is paramount because it provides student-teachers with a great foundation to get to know what to aim for and how to achieve it; it is in other words, their horizon and guidelines. This planning stage must be connected to the pedagogical project to tackle teaching goals and aims.

Learning and teaching objectives must be clearly defined and linked to the problem diagnosed earlier in the observational stage or the challenges student-teachers wish to pursue. They serve as guidelines to facilitate the comprehension of "goals and the congruence between stated goals, and the activity students are engaged in" (Helle et al., 2006). In fact, when student-teachers know perfectly what they are looking for, their arguments are grounded and supported. One of the commonest difficulties reported by student-teachers in this respect is that they did not distinguish the difference between the aims that are called teaching or personal aims (what the teacher wishes to achieve for himself professionally or linguistically, for example to gain students' rapport more easily), the main aims or learning aims which are expressed in terms of functions and competencies and refer to what student will be able to do by using the new language (for instance, student will be able to describe a picture in groups) and the aims that are called subsidiary, in which normally student-teachers focus just on grammar, ignoring the existence of other fields as sociolinguistics, pragmatics, culture, and the chance to explore interdisciplinarity or apply an inquiry-based teaching. 
After student-teachers defined their aims, they proceeded to describe the activities they would carry out, in what is known as implementation stage. Such stage gives an account of what materials and resources will be used, what type of enabling tasks will be conducted. They also described how the activities were going to be implemented step by step. We observed that since student-teachers were quite knowledgeable of the famous P.P.P planning model (Presentation, Practice and Production), they tried to make the most of it, and replicated it to all types of classes and environments regardless of the method or approach they said they had chosen. In doing so, student-teachers did not realise that this was just a format or template, which they should modify or adjust to their interest. Using the P.P.P model for instance, would not be suitable to plan a lesson in a project-based approach (Willis, 1996), since class based on projects are not as structured as is a grammar oriented one.

Similarly, in this line of thought, student-teachers got used to mislabelling everything as "activities". Sometimes, what they showed in their planning was a list of isolated steps that corresponded mostly to mechanical exercises or drillings rather than an activity per se, and for instance when they manifested that they were planning a task-based lesson, it was found that there was not a description of a task as such but of a regular activity which lacked different elements to be conceived of a task. (Nunan, 1989).

Furthermore, we as mentors came across the fact that warming up activities though entertaining, looked disconnected from the rest of the planning because student-teachers did not manage to show the connection between that very first moment of the class (ordinarily a game, lottery, or charades) with the main topic and the activities proposed, with the transition between the initial part of a class and with what was called practice, as illustrated in the chart below.

Table 1. Sample student-teacher's lesson plan

\begin{tabular}{|c|c|c|c|}
\hline $5 \mathrm{~min}$ & Warm up & $\begin{array}{l}\text { Stand the students and call out instructions: } \\
\text { "Jump } 10 \text { times", "Turn around } 4 \text { times" etc. } \\
\text { Other good ones to use are: run (on the spot), } \\
\text { hop, hands up \& down, touch your (body part), } \\
\text { stand up \& sit down and star jump. This one is } \\
\text { great for classroom commands and numbers. }\end{array}$ & \\
\hline $2 \mathrm{~min}$ & $\begin{array}{l}\text { Introducing the } \\
\text { topic } \\
\text { objectives }\end{array}$ & $\begin{array}{l}\text { Good morning! Today we are going to move a } \\
\text { lot! Are you ready? Let's start! }\end{array}$ & \\
\hline $10 \mathrm{~min}$ & $\begin{array}{l}\text { Development } \\
\text { (video) }\end{array}$ & $\begin{array}{l}\text { Before: We're going to watch a video. Are you } \\
\text { ready? } \\
\text { During: Students will move as the video says. } \\
\text { The teacher should join students and do it too. } \\
\text { After: The teacher will ask students which steps } \\
\text { they remember from the video. }\end{array}$ & $\begin{array}{l}\text { If the kids do not remember } \\
\text { any step, the teacher will } \\
\text { repeat the song one more } \\
\text { time. If the still do not know, } \\
\text { the teacher will play the song } \\
\text { and he will pause it every time } \\
\text { a new movement is done. } \\
\text { Then, he will ask students } \\
\text { what they said in the video. }\end{array}$ \\
\hline
\end{tabular}

Another issue that was clearly identified in the template above was the little importance that student-teachers assigned to something relevant as the evaluation process. Most of the times, what they called production stage entailed exercises or activities in which evaluation, and the way they planned to assess their students were not included. In the best-case scenario, when they made evaluation explicit, it was not consistent with the aims they set up at the beginning of the lesson or it became grammar-focused.

\subsection{A Behaviouristic Classroom Management Focus}

It is worth mentioning that indeed a large percentage of the participants possessed a quite good command of the English language which they praised a lot, and thought of being enough to manage a class. Traditionally, managing a class is associated to the idea of advocating for quiet and highly disciplined students. Nevertheless, as Raizen, 2010; Everstone and Weinstein (2006) support, classroom management would comprise other aspects different from disciple such as facilitating and fostering an environment for learning, and for the socio-emotional development of students. In an inquiry-based practicum, this last component is crucial to promote empathy and 
to set the atmosphere to think the context critically so that students are motivated, focused, and engaged in solving problems while using English. When we observed student-teachers in their actual classrooms, at least in the first observations, it was clear that the good command of English they had cultivated and praised did not help them so much in involving students in the activities they were leading; this means students did not have it clear what to do or how to do it properly, the class itself was interrupted first by students' behaviour and attitudes as noise, indiscipline, disruption, bullying, and then by external and institutional factors that were inherent to the school, it means as well that the only possible way student-teachers were used to showing they had classroom management was keeping students busy all the time but not necessarily relaxed and pleasant (Sanford, Emmer and Clements, 1983).

\subsection{Undervaluing Their Own Performance}

Within an inquiry practicum the kind of assessment that is called for is one in which the student-teacher recognises himself as a potential good teacher, identifying those aspects in which he thrives, and equally those in which he needs to improve by acknowledging his concern about his own students' learning process. In our view, we conceive of an inquiry practicum as the scenario where student-teachers look constantly to grow professionally, academically and personally as educators without aspiring to become an ideal teacher or compare to a preexisting role model for teachers. The practicum, therefore, consolidates as the setting to empower themselves as teachers who wish to be their very best version. This implies making the most of their own strengths and personality traits, even if they do not fit standard views on language teachers, for instance if they speak in a high pitch, they can use their voice as an engaging device, and if they are said to be shy to teach, they can understand how their own practicum helps them cope with it, and why the fact of being shy does not necessarily interfere with being a successful teacher or not.

When student-teachers were prompted to assess themselves, they recalled that imagined identity (Anderson, 1991) embedded in the notion of an ideal teacher. That made them live a conflict of interests because they wanted to become that ideal teacher, and at the same time they found it hard to understand that ideal teachers do not exist just because a teacher's identity may be constituted in relation with others (students, other educators, institution, parents, etc.). Influenced greatly by the notion mentioned above, they were prone to underestimating their own performance as teachers, for instance, when they did not get the linguistic outcomes from their students immediately. Not having achieved those expected results, meant frustration to them and made them refer to their own proposal as a failure. In our view as mentors, learning does not obey to immediate results particularly in the field of foreign languages but to a complex process that takes up time, commitment and investment.

\section{Discussion}

After having reflected collaboratively upon the results revealed by the data collected, we will provide some outstanding comments and insights that we think should be taken into consideration, if public universities in Colombia intend to improve the teaching experience of their student-teachers, and ultimately, if they wish to improve their practicum as a whole in the long run.

The observational process carried out by both student-teachers and their mentors over a long period, revealed that it was possible to understand the schools context, by context here we do not refer solely to the physical, tangible and most immediate ambiance which surrounds the student-teachers' practicum. In a broader sense, understanding the school context would imply the understanding of how local, national and even transnational education policies regarding foreign language and how to educate and take care of children and adolescents affect the schooling process in general, and English teaching in particular.

In trying to understand the context, it was paramount to conduct a good needs analysis from the very beginning. As student-teachers failed to do it at an early stage, that led them to overgeneralise situations and misunderstand practices that happened in class; mistakenly, they rushed to the worn-out conclusion that regardless of the classroom and grade they were teaching, the same problems arose everywhere: lack of motivation, lack of vocabulary and lack of interaction, which ranked fairly on top of student-teachers commonest identified issues.

Another challenging situation experienced by student-teachers was to write up a contextualised rationale. The most difficult part for them to devise was to define the institutional framework. Student-teachers were expected to make a rationale that gave a comprehensive account of their understanding of the school; by way of example, student-teachers had to situate their proposal within the institutional context (mission, vision, school projects) and a pedagogical focus (critical thinking, meaningful learning, cooperative learning, etc.). Nevertheless, in doing so, the pedagogical focus they chose appeared to be ineffective for different factors as the scarce conditions and resources the school had, the inexperience of the student-teachers to implement the pedagogical 
proposal itself, the resistance home teachers showed in regard to that proposal, the school reluctance to support student-teachers novel proposals because they might alter or interfere with other interests, and in other cases, in spite of the fact that the students whom our student-teachers were instructing displayed good attitude towards those proposals, their socioeconomic conditions and logistics in general hindered the success of such initiatives.

Both student-teachers and mentors recognised that in the schools observed, the contents of the syllabi were arranged revolving around grammar structures or decontextualised vocabulary and this at first sight, made student-teachers echoe grammar focus teaching where innovation was not taken into account. For us as mentors, it was a daunting task to explain to them that grammar should be important but that it could be taught in different ways, not solely in the realm of structuralism. Once again, student-teachers advocated for the use of templates, and requested to be shown a sample for them to understand the way grammar aims should be addressed more clearly.

In the implementation stage, student-teachers were prompted to create, tailor, adjust or redesign some activities that they had taken from other sources, and which dealt with foreign contexts (for example a dialogue in an underground station versus a dialogue in a local public means of transport) to facilitate their students' comprehension of English as a vehicle of communication,consequently, when they talked about their own context they could realise that language was a means, and not just an end. Despite student-teachers knew of this well in advance, it was evident that for them fostering English as a communication means, and not as an end was overwhelming: they tried to favour or enhance just one communicative skill or two utmost. They focused activities mostly on reading or basic writing exercises, and rarely did they integrate skills such as listening and speaking. If they said they were working on communicative skills, what they really ended up working on was grammar or vocabulary, for instance when they manifested openly that they were dealing with writing, what they indeed proposed was a grammar exercise like writing ten sentences in past simple.

As mentors, we were aware of the fact that our presence in their classroom might have caused a great deal of intimidation in our student-teachers during the different phases, particularly in the implementation stage; therefore, we invested a lot of commitment to gain their confidence and trust because the mutual understanding of teaching implications was important to discuss later on about the difficulties, and good decisions they had made in class. Some of the most recurrent topics that both mentors and student-teachers brought up in their weekly meetings were specifically all the issues derived from timing (balancing out activities in terms of real time invested and needed), ownership (that they really looked ready, prepared and professional in their classes) and empowerment (that students recognised themselves as teachers and as an authority, and not as "practitioners" who were just teaching them English.

It is important to stress out that in our inquiry-based practicum, we as mentors, did not aim to homogenise student-teachers precisely because it was clear that each and every of them had a strength and personality traits which endowed the teaching of English with something unique. In our pursuit of an inquiring student-teacher, we were more interested in promoting a genuine concern for their students' learning; being a real facilitator of their capabilities to questions the world, to formulate the right questions, to look for the best strategies to answer them, to solve problems while learning English, to infer meaning; being able to help their own students to realise that they were unique and therefore, different one from the other, and that the classroom was not a space to contend for learning but a scenario to share, to grow together, and to construct knowledge.

Most of the skills we were looking forward to fostering in them as student-teachers, embodied the essence of an inquiry-based practicum. In this respect, we observed how student-teachers struggled to teach English within an inquiry-based practicum for different reasons. In the first place, they had a hard time applying their pedagogical proposals, not because these were not solid or well-grounded but mainly because of the prevailing perceptions they had on language and the way they thought it should be taught. For example, in principle they missed out the opportunity to foster their students' capabilities through critical pedagogy, projects, tasks or collaborative learning because they worried too much about their students' English level, just because English still meant an end to them. In our view, this was one of the most conflicting barriers we had to help them to overcome: to make them be aware that English should not be in all cases an end but a means; that English could be the tool to learn about other subjects as in a CLIL class, to develop a project, to interact with others or to experience a cultural practice.

One factor that added up to this situation and deprived student-teachers of the possibility to promote new pedagogical proposals in their classes, was the enormous importance they granted to the use of English in their classes, as they claimed that for their practicum to be effective they had to speak English all the time and therefore, the use of Spanish was not only undesirable but banned. To us, the strategic use of Spanish was 
welcome when the conditions for implementing a particular pedagogical proposal required it, and when the conditions to use English one hundred percent were not given, and became somehow unfair to students.

Moreover, upon exploring deep into the methodology student-teachers opted out for, we noticed that they held an enrooted concern for a very schematic methodology, which is absolutely understandable for novice teachers, but in doing so, they mainly focused on developing the number of activities they had planned for; they exhibited a deep interest for procedures; and somehow neglected substantial aspects for class development, for example if their students had really understood; if they were engaged in class; if they had done the activity well; if they needed further time to accomplish a task; if their opinions were relevant, their stances well-grounded , and their participation meaningful to bring the inquiry cycle to completion.

\section{Conclusions}

Some important conclusions that can be drawn out of what we have said along this study revolve around two main aspects: what we as mentors think an inquiry-based practicum entails, and a reflection upon the most noticeable difficulties arisen in this process for student-teachers. That reflection is paramount in a practicum of this type for student-teachers to understand the importance of such a practicum for their growth and empowerment, to adjust to their own teaching context, to overcome their own difficulties, and for us as mentors to incorporate the due changes in our practicum, and reformulate the way we lead that guidance.

One of the top priorities aimed for in this inquiry based-practicum, was that student-teachers should be able to give an account of the teaching context they were involved in by adjusting to it, by comprehending it, by constantly identifying opportunities to improve it, by recognising what all individuals who were part of it could bring in, by making the best decisions to transform that local reality, by actively engaging in interdisciplinary projects which made language transcend classroom practices.

As mentors, we found out that some student-teachers fit in their new contexts more easily since they recognised and appreciated the fact that the practicum was an opportunity to get to know even themselves in their new roles as teachers; they were constantly keeping us posted on what was happening in their process; they were eager for feedback; they incorporated suggestions; they shared ideas that emerged from their own practice; they posed questions to us and to themselves; and they displayed initiatives, and empathy with their students.

Notwithstanding, some student-teachers struggled to understand their new school because they were tied to the ordinary and schematic class design and conventional teachers' role, furthermore, they were not able to problematise theory, the context itself and even their roles, and their own performance. We understand that is not easy for novel teachers to rate difficulties and to avoid overlooking the substantial issues. Sometimes, they worried too much about the effectiveness or ineffectiveness of a class in lieu of focusing on the meaningfulness of the whole process.

To guide student-teachers to understand their teaching context more effectively, is a must that mentors in general get really engaged in that school setting where their student-teachers will be teaching. That is why, we suggest that mentors should constantly visit the school prior to the beginning of the practicum, and during the whole process. We also suggest setting some agreements and expectations with the principal and the head teachers, looking into all institutional documents and sources so that student-teachers can foresee difficulties that might arise in the long run as well as growth opportunities for themselves.

Another way through which mentors can foster student-teachers' understanding their own teaching reality is by having them reflect through critical questions upon the new experience they are living as teachers, the decisions that they make, the plan they devise, and the project they design. Furthermore, it is advisable to entice them to constantly question their own performance by asking themselves, for example the reasons behind the decisions they make in every activity, the class aims they select, the skills and sub skills they prioritise in their planning, (linguistic and cognitive ones); the end is to recognise in a critical assessment, an opportunity to improve as teachers, and when a teacher understands himself, he might find it easier to transform his reality.

Aside from the observation process that student-teachers should conduct, we as mentors suggest assigning selected reading texts every week for them to understand their reality much better, and to support the decisions they make in an informed fashion. In our case, discussions in the initial practicum meetings revolved around helping them to clarify ideas about the information they had gathered initially, and to try to use that information to improve their instructional design or/and pedagogical project with the acknowledgement of the hard task they had to perform to motivate their students to be engaged in their English class.

After this research experience, both mentors and student-teachers have realised the importance of leading consistent questions in a syllabus because doing it withing an inquiry -based methodology is an important feature 
of the practicum to guide a reflective teaching, as it is explained better in Zeichner and Liston's (1996) words: "If a teacher never questions the goals and the values that guide his or her work, the context in which he or she teaches, or never examines his or her assumptions, then it is our belief that this individual is not engaged in reflective teaching" (p. 1). In this study, discussion sessions were fundamental to create the conditions in order to facilitate self/peer assessment and peer-evaluation so that our student-teachers could have informed stances about their practice.

In relation to the critical skills that student-teachers should develop, it was evident that within this inquiry-based practicum, they were constantly urged to see themselves as agents and critical beings of that context they were teaching by being aware of the importance of understanding that children did not have the chance to practice English at home; by understanding that the number of hours of instruction despite the ordinance of the National Ministry of Education was not enough to fulfil the requirements set forth by the Common European Framework; by comprehending that the daily and ongoing activities held in the Colombian schools at which they conducted their practicum,clashed with English time class, and that on account of this, English class was relegated to a second position or it was simply cancelled; by understanding that most kids and teenagers were not intrinsically motivated to learn English but that English meant a requirement, and sometimes, an obstacle they needed to overcome.

Student-teachers were also able to become more critical of their own performance by coming to terms with the multiple duties as teachers they were entrusted, as being responsible and accountable for not just instructing but also for facilitating children and teens' socialisation process, for taking full care of them physically and emotionally, for promoting in their class values such as respect, tolerance, forgiveness, peace, reconciliation that went hand in hand with the national feeling that our country had been cherishing.

\section{References}

Anderson, B. (1991). Imagined Communities: Reflection and Origin and Spread of Nationalism (rev. edn.). London: Verso

Barron, B., Schwartz, D., Vye, N., Moore, A., Petrosino, A., \& Zech, L. (1998). The Cognition and Technology Group at Vanderbilt. Doing with understanding: Lessons from research on problem- and project-based learning. Journal of the Learning Sciences, $7(3 \& 4), \quad$ 271-311. https://doi.org/10.1080/10508406.1998.9672056

Beck, S. (2001). Editor's Reviews of Vygotskian Perspectives on Literacy Research: Constructing meaning through collaborative inquiry and inside city schools: Investigating Literacy in multicultural Classrooms. Harvard Educational Review, 71(2), 296-310. http://doi.org/10.17763/haer.71.2.c10541380w62g260

Bergin, J. (2002). Fourteen pedagogical patterns. Available: http://csis.pace.edu/ bergin/PedPat1.3.html

Brew, A. (2006). Research and teaching: Beyond the divide. London: Palgrave Macmillan.

Biggs, J. (1999). Teaching for quality learning at university. Buckingham: Open University Press.

Biggs, J. (2003). Teaching for Quality Learning at University. Buckingham: SRHE/OUP

Bonilla, S., \& Méndez Rivera, P. (2008). Mentoring in pre-service teaching: from reflection on practice to a didactic proposal. Actualidades Pedagógicas, 0(52), 79-90. http://dx.doi.org/10.19052/ap.1328

Bransford, J., Vye, N., Stevens, R., Kuhl, P., Schwartz, D., Bell, P., ... Sabelli, N. (2006). Learning Theories and Education: Toward a Decade of Synergy. In P. Alexander, \& P. Winne (Eds.), Handbook of Educational Psychology (Second Edition, pp. 209-244). Mahwah, NJ: Erlbaum.

Burns, A. (1999). Collaborative Action Research for English Language Teachers. Cambridge: Cambridge University Press.

Burns, A. (2010). Doing Action Research in English Language Teaching. New York: Routledge.

Candy, P., Crebert, G., \& O'Leary, J. (1994). Developing lifelong learners through undergraduate education. Canberra: Australian Government Publishing Service. Retrieved from http://hdl.voced.edu.au/10707/94444

Conole, G., Dyke, M., Oliver, M., \& Seale, J. (2004). Mapping pedagogy and tools for effective learning design. Computers \& Education, 43(1-2), 17-33. https://doi.org/10.1016/j.compedu.2003.12.018

Cochran-Smith, M., \& Lytle, S. L. (2001). Beyond certainty: Taking an inquiry stance on practice. In A. Lieberman, \& L. Miller (Eds.), Teachers caught in the action: Professional development that matters (pp. 45-58). New York: Teachers College Press. 
Dart, B. (1998). Teaching for improved learning in small classes. In G. Boulton-Lewis (Ed.), Teaching and learning in higher education (pp. 222-249). Melbourne: The Australian Council for Educational Research Ltd.

Delors, J. (1996.): Los cuatro pilares de la educación. En La educación encierra un tesoro. Informe a la UNESCO de la Comisión internacional sobre la educación para el siglo XXI, Madrid, España: Santillana/UNESCO. pp. 91-103.

Evertson, C. M., \& Carol, S. W. (2006). Handbook of Classroom Management: Research, Practice, and Contemporary Issues. Mahwah, New Jersey: Lawrence Erlbaum Associates.

Gay, G. (2010). Culturally responsive teaching: Theory, research, and practice. New York: Teachers College Press.

Gray, P. J., Froh, R. C., \& Diamond, R. M. (1992). A national study of research universities on the balance between research and undergraduate teaching. Syracuse, NY: Syracuse University Center for Instructional Development.

Goodyear, P., \& Yang, D. F. (2009). Patterns and pattern languages in educational design. In L. Lockyer, S. Bennett, S. Agostinho, \& B. Harper (Eds.), Handbook of research on learning design and learning objects: Issues, applications and technologies (Vol 1. pp. 167-187). Hershey, PA: Information Science Reference. https://doi.org/10.4018/978-1-59904-861-1.ch007

Helle, L., Tynjala, P., \& Olkinuora, E. (2006). Project based learning in post-secondary educationtheory,practice and rubber sling shots. Higher Education, 51(2), 287-314. https://doi.org/10.1007/s10734-004-6386-5

Johnson, K. (1999). Understanding language teaching: Reasoning in action. Boston: Heinle \& Heinle. https://doi.org/10.1177/136216889900300301

Linn, V., \& Jacobs, G. (2015). Inquiry-Based Field Experiences: Transforming Early Childhood Teacher Candidates' Effectiveness. Journal of Early Childhood Teacher Education, 36(4), 272-288. https://doi.org/10.1080/10901027.2015.1100143

Méndez, P., \& Bonilla, X. (2016). Diseño, implementación y evaluación de prácticas pedagógicas en un programa de Licenciatura con énfasis en inglés. Colomb.Appl.Linguist.J., 18(2), 49-66.

Méndez, P. (2013). Currículo en la formación docente. Una propuesta de lineamientos interdisciplinarios para fortalecer las prácticas docentes. Bogotá: Fondo de Publicaciones Universidad Distrital Francisco José de Caldas

Mills, G. (1999). Action Research: A guide for the Teacher Researcher. Prentice

Nicol, D., \& MacFarlane-Dick, D. (2006). Formative assessment and self-regulated learning: A model and seven principles of good feedback practice. Studies in Higher Education, 31(2), 199-218.

Nguyen, H. T. (2009). An inquiry-based practicum model: What knowledge, practices, and relationships typify empowering teaching and learning experiences for student teachers, cooperating teachers and college supervisors? Teaching and Teacher Education, 25(5), 655-662. https://doi.org/10.1016/j.tate.2008.10.001

Norton, B., \& K. Toohey (eds.) (2004). Critical pedagogies and language learning. New York: Cambridge University Press. https://doi.org/10.1017/CBO9781139524834

Nunan, D. (1989). Syllabus Design. Oxford: Oxford University Press.

Olaya, A., \& Gómez, R. L. F. (2013). Exploring EFL Pre-Service Teachers' Experience with Cultural Content and Intercultural Communicative Competence at Three Colombian Universities. Profile Issues in Teachers Professional Development, 15(2), 49-67.

Raizen, E. (2010). Management, discipline and control. Retrieved from http://coerll.utexas.edu/methods/modules/classroom/01/

Richards, J. y Lockart, C. (1994). Reflective Teaching in Second Language Classrooms. Cambridge: CUP. https://doi.org/10.1017/CBO9780511667169

Reigeluth, C. M. (1999a). What is instructional-design theory and how is it changing? In C. M. Reigeluth (Ed.), Instructional-design theories and models: A new paradigm of instructional theory (Vol. II, pp. 5-29). Mahwah, NJ: Lawrence Erlbaum Associates.

Sagor, R. (2005). The Action Research Guidebook. Thousand Oaks, Corwin Press. 
Sanford, J. P., Emmer, E. T., \& Clements, B. S. (1983). Improving classroom management. Educational Leadership, 40(7), 56-60.

Schon, D. (1983). The Reflective Practitioner: How Professionals Think in Action. (1995 ed.). Aldershot: Ashgate Publishing Ltd.

Wiggins, G., \& McTighe, J. (2011). The Understanding by Design guide to creating high-quality units. Alexandria, VA: ASCD.

Willis, J. (1996). A Framework for Task-Based Learning. London: Longman

Wolverton, M. (1998). Treading the tenure-track tightrope: Finding balance between research excellence and quality teaching. Innovative Higher Education, 23(1), 61-79. https:/doi.org/10.1023/A:1022972530179

\section{Copyrights}

Copyright for this article is retained by the author(s), with first publication rights granted to the journal.

This is an open-access article distributed under the terms and conditions of the Creative Commons Attribution license (http://creativecommons.org/licenses/by/4.0/). 